\title{
Nitrogen and Fungicide Applications for the Management of Fungal Blights of Carrot
}

\author{
Catarina Saude and Mary Ruth McDonald ${ }^{1}$ \\ Department of Plant Agriculture, University of Guelph, 50 Stone Road East, \\ Guelph, Ontario, Canada N1G 2W1
}

\section{Sean Westerveld \\ Ontario Ministry of Agriculture and Food and Ministry of Rural Affairs, 1283 Blueline Road, Simcoe, Ontario N3Y 4N5}

Additional index words. Alternaria dauci, ammonium nitrate, Cercospora carotae, Daucus
carota spp. sativus, fungicides

Abstract. Alternaria leaf blight (ALB) caused by Alternaria dauci (Kühn) Groves and Skolko and Cercospora leaf spot (CLS) caused by Cercospora carotae (Pass.) Solheim are the major foliar diseases of carrot in Ontario, Canada. In addition to reducing photosynthetic area, the diseases can weaken carrot tops, which can break during mechanical harvesting, reducing harvested yields. Fungicides are commonly used to manage the disease, but there is potential to reduce fungicide applications through nitrogen (N) management. Trials were conducted on mineral soils from 2006 to 2008 to determine the importance of applied $\mathbf{N}$ and fungicide applications to control fungal leaf blights of carrot. Three rates of $N\left(0,110\right.$, and $\left.220 \mathrm{~kg} \cdot \mathrm{ha}^{-1}\right)$ and 0,3 , or $5(2006$ and 2007) or $6(2008)$ fungicide applications were applied. Leaf blight severity was assessed biweekly throughout the season and at harvest. The severity of both ALB and CLS and combined disease severity index at harvest decreased with increasing $\mathbf{N}$ and fungicide application. In some cases, disease severity of carrots treated with high $\mathrm{N}$ and no fungicides was equivalent to carrots treated with no $\mathrm{N}$ and five fungicide sprays. Total and marketable yield increased with increasing number of fungicide sprays in 2006 and 2007, but $\mathbf{N}$ application did not affect yield. Results suggest that severity of ALB and CLS can be minimized through a combination of $N$ and fungicide applications, but rates of $N$ higher than $110 \mathrm{~kg} \cdot \mathrm{ha}^{-1}$ may reduce marketable yield through a decrease in stand and an increase in oversized roots.

Alternaria leaf blight and CLS caused by the mitosporic fungi Alternaria dauci (Kühn) Groves \& Skolko and Cercospora carotae (Pass.) Solheim, respectively, are the major foliar diseases of carrot [Daucus carota L. subsp. sativus (Hoffm.) Arcang] in Canada (Carisse and Kushalappa, 1992) and in many other regions of the world (Ben-Noon et al., 2001; Gugino et al., 2004; Pryor and Strandberg, 2002). Both $A$. dauci and $C$. carotae infect leaves and petioles of carrot causing damage to the carrot foliage. Alternaria leaf blight symptoms occur on mature or senescing foliage and are characterized by irregularly shaped necrotic lesions along leaf margins (Hooker, 1944). Cercospora leaf spot symptoms occur on both mature and new foliage and include small necrotic lesions surrounded by a chlorotic halo (Thomas, 1943).

In Ontario, the largest carrot producer in Canada, 3683 ha of carrot were grown in 2012 resulting in a farm gate value of $\$ 34.5$ million [Ontario Ministry of Agriculture and Food (OMAF, formerly the Ontario Ministry of Agriculture, Food and Rural Affairs,

Received for publication 17 Oct. 2013. Accepted for publication 7 Mar. 2014.

${ }^{1}$ To whom reprint requests should be addressed; e-mailmrmcdona@uoguelph.ca.
OMAFRA), 2013]. Yield losses of carrot resulting from fungal leaf blights can be considerable with as much as $40 \%$ to $60 \%$ of the yield lost (Vintal et al., 1999). Losses are associated with reduction of the leaf photosynthetic area and weakening of the petioles induced by the leaf blight pathogens. Infected and weakened petioles often break during mechanical harvest, leaving the root in the ground (Langenberg, 1975). These remaining roots cannot be economically harvested. Therefore, vigorous and healthy carrot foliage is essential to maximize carrot yield.

Host nutrition is an important factor affecting the severity of fungal blights of carrot. Fertilization can influence the resistance of plants to pathogens (Huber and Watson, 1974; Marschner, 1995) by delaying leaf senescence. A relationship between fertilization practices with phosphorous $(\mathrm{P})$, potassium $(\mathrm{K})$ and $\mathrm{N}$ and leaf blight on tomato (Lycopersicon esculentum Mill.) and potato (Solanum tuberosum L.) has been established, but the reported effects were inconsistent and varied by pathogen, crop evaluated, and type and formulation of the fertilizers applied (Blachinski et al., 1996; MacKenzie, 1981; Soltanpour and Harrison, 1974; Vintal et al., 1999; White et al., 1983). For instance, on carrot, ALB severity was reduced by increasing $\mathrm{N}$ application rate in Michigan (Warncke,
1996), Ontario (Westerveld et al., 2002), and Israel (Vintal et al., 1999). For CLS, severity decreased with increasing $\mathrm{N}$ application rate in Ontario (Westerveld et al., 2008) but increased with increasing $\mathrm{N}$ application rate in controlled environment studies (Thomas, 1943). No relationship was found between CLS and foliar $\mathrm{N}$ concentrations in the field in another study, but this study did not examine the direct effect of $\mathrm{N}$ application rate on disease severity (Tremblay and Charbonneau, 1993).

Because excessive rates of fertilizers can be harmful to the environment and to subsequent crops, excessive fertilization is not recommended. Research conducted with crops such as tomato, potato, and cotton in which different rates of fertilizers and fungicides were combined to control leaf blight caused by Alternaria spp. showed that crops should be fertilized for optimal yield and ALB should be managed by properly timed applications of fungicides during the growing season (Blachinski et al., 1996; Vintal et al., 1999). In relation to fungal leaf blights of carrot, a recent study conducted in Ontario suggested that $\mathrm{N}$ application rate could be used to reduce the need for fungicide applications to control disease in the field (Westerveld et al., 2008). In this study, we intended to investigate if $\mathrm{N}$ application could be used to replace some fungicide sprays on carrots, thus reducing grower input costs. Therefore, the main objectives of this study were: 1) to evaluate the effect of $\mathrm{N}$ rates and the number of fungicide applications for control of ALB and CLS of carrot; 2) to determine if the $\mathrm{N}$ application rates that reduced the severity of fungal leaf blights on carrots could replace some of the fungicide applications; and 3) to determine yield responses as a result of the combined effect of $\mathrm{N}$ and fungicide applications.

\section{Materials and Methods}

Field plot establishment. One field trial was established each year from 2006 to 2008 on three different sites of a mineral soil field (dark gray gleysol-Granby sandy loan) containing $2.6 \%$ organic matter and $\mathrm{pH} 8.1$ (2006 experiment site) and $4.9 \%$ organic matter and $\mathrm{pH} 7.1$ (2007 and 2008 experiment sites) on the Holland/Bradford Marsh (lat. $44^{\circ} 15^{\prime} \mathrm{N}$, long. $77^{\circ} 90^{\prime} \mathrm{W}$ ) near the University of Guelph, Muck Crops Research Station, Ontario, Canada. Carrot cultivar Enterprise (Stokes Seeds, Thorold, Ontario, Canada) was used in all three field experiments.

The sites used for these experiments were known to have high residual $\mathrm{N}$ levels as a result of high organic matter content for a sandy soil. Carrots grown on both organic and mineral soils have been shown to recover large amounts of $\mathrm{N}$ from the soil (Westerveld, 2002). Carrots were planted and harvested on each trial site the year before each trial in an attempt to decrease residual $\mathrm{N}$ levels and thus to increase the $\mathrm{N}$ response of carrots during the experimental phase. This was used to simulate more typical mineral soils used for carrot production in Ontario, which are often 
very low in both organic matter and residual $\mathrm{N}$. For the three experiments, carrots were directseeded $(80$ seeds $/ \mathrm{m})$ on raised beds using a Stan Hay Precision seeder on 29 May 2006, 22 May 2007, and 2008. Each experimental unit consisted of four rows, $8 \mathrm{~m}$ long, $20 \mathrm{~cm}$ high, spaced $86 \mathrm{~cm}$ apart at a seeding rate of $80 \mathrm{seeds} / \mathrm{m}$. A randomized complete block design with four replications per treatment was used. Phosphorus and $\mathrm{K}$ fertilizers were applied according to OMAFRA recommendations based on preplant soil $\mathrm{P}$ and $\mathrm{K}$ concentration (OMAFRA, 2012). Weeds and insects were managed according to recommended commercial practices (OMAFRA, 2012).

Nitrogen rates and fungicide applications. The trial consisted of all combinations of three $\mathrm{N}$ application rates and three fungicide regimes. Nitrogen was applied at 0,110 , and $220 \mathrm{~kg} \cdot \mathrm{ha}^{-1}$ split $67 \%$ preplant and $33 \%$ sidedressed when plants were 10 to $15 \mathrm{~cm}$ tall, which equated to $0 \%, 100 \%$, and $200 \%$ of current Ontario recommendations (OMAFRA, 2012). Ammonium nitrate $(34 \% \mathrm{~N})\left(\mathrm{NH}_{4} \mathrm{NO}_{3}\right)$ was used for $\mathrm{N}$ fertilization in each trial year and was spread evenly over each plot by hand. Soil samples at 0 - to $20-\mathrm{cm}$ depth were taken before seeding each carrot crop. Soil mineral $\mathrm{N}\left(\mathrm{NO}_{3}{ }^{-}\right)$was determined (A\&L Canada Laboratories Inc., London, Ontario, Canada). Soil mineral $\mathrm{N}$ was extracted using cadmium reduction and $\mathrm{NO}_{3}-\mathrm{N}$ was quantified by automated colorimetric analysis (Jones, 1999).

The three fungicide regimes consisted of zero, three, or five (six in 2008) applications of fungicides over the growing season. The fungicides used were LANCE WDG (220 g.ha ${ }^{-1}$ a.i. boscalid; BASF Canada Inc., Ontario, Canada), BRAVO 500 (1.5 L $\cdot \mathrm{ha}^{-1}$ a.i. chlorothalonil; Syngenta Crop Protection Canada Inc., Ontario, Canada), and CABRIO EG (220 g.ha ${ }^{-1}$ a.i. pyraclostrobin; BASF Canada Inc.). These fungicides are registered for control of fungal blights of carrot in Canada and are typically used by carrot growers in a rotation to reduce the development of resistance. In 2006, the fungicides boscalid, chlorothalonil, and pyraclostrobin were applied on 1 and 10 Aug. and 22 Sept., respectively, for the three-application regime

Table 1. Rating scale used for Alternaria leaf blight and Cercospora leaf spot severity of carrots grown on mineral soil near Muck Crops Research Station, Holland Marsh, in 2006, 2007, and 2008.

\begin{tabular}{cc}
\hline Rating & Description \\
\hline 0 & No lesions \\
1 & 1 to 10 lesions on leaves \\
2 & 11 to 20 lesions on leaves \\
3 & 21 to 30 lesions on leaves, \\
& 1 to 10 lesions on petioles \\
4 & 31 to 40 lesions on leaves, \\
& 11 to 20 lesions on petioles \\
5 & 41 to 60 lesions on leaves, \\
6 & 21 to 40 lesions on petioles \\
7 & $>60$ lesions on leaves, $>40$ lesions \\
8 & on petioles \\
9 & $1 \%$ to $25 \%$ of leaves destroyed \\
10 & $26 \%$ to $50 \%$ of leaves destroyed \\
& $51 \%$ to $75 \%$ of leaves destroyed \\
\end{tabular}

and on 1 Aug. (boscalid), 10, 18, and 28 Aug. (chlorothalonil), and 22 Sept. (pyraclostrobin) in the five-application regime. In 2007, the fungicides boscalid, chlorothalonil, and pyraclostrobin were applied on 17 and 29 Aug. and 17 Sept., respectively, for the threeapplication regime. The fungicide boscalid was applied on 17 Aug. and 10 Sept., chlorothalonil was applied on 29 Aug. and 27 Sept., and pyraclostrobin was applied on $17 \mathrm{Sept}$. for the five-application regime. In 2007, an additional treatment was included in the trial, which was $220 \mathrm{~kg} \cdot \mathrm{ha}^{-1} \mathrm{~N}$ applied as $\mathrm{NH}_{4} \mathrm{NO}_{3}$ and a half rate of the same fungicides and timing included in the five-fungicide regime. In 2008, the fungicides in the three-fungicide regime were applied on 1 and 23 Aug. and 22 Sept. and matched the fungicides used in the six-fungicide regime. A six-fungicide treatment regime was used instead of a fivefungicide regime in 2008, and both full and half fungicide rate treatments were included at each $\mathrm{N}$ rate. These fungicides were applied on 1 and 23 Aug. (pyraclostrobin), 12 Aug. and 12 Sept. (chlorothalonil), and 3 Sept. and 22 Sept. (boscalid). The use of half rates of the fungicides (2007 and 2008) aimed to determine if a greater resistance to fungal leaf blights as a result of $\mathrm{N}$ applications could allow for a reduced rate of fungicides. Fungicides were applied using a pull-type plot sprayer with Teejet D-3 hollow cone nozzles at $690 \mathrm{KPa}$ (boom) in $500 \mathrm{~L} \cdot \mathrm{ha}^{-1}$ of water.

Carrot fungal leaf blight assessments. ALB and CLS occurred naturally in the field and were the only leaf blights that infected carrots. Once symptoms of the diseases developed, carrot foliage was rated biweekly for both ALB and CLS up to 1 week before harvest. At each rating, the canopy was assessed at five locations selected at random within the middle two rows of each experimental unit. The amount of disease on leaves and petioles was estimated and assigned a rating according to a rating scale of 0 to 10 (Table 1). Biweekly disease ratings were used to calculate area under the disease progress curve (AUDPC) using the equation:

$$
\mathrm{AUDPC}=\sum_{j=1}^{n j-1}\left(\frac{y_{j}+y_{j+1}}{2}\right) \quad\left(t_{j+1}-t_{j}\right)
$$

where $y=$ leaf blight severity rating at $j$ th observation, $t=$ time (days) since the previous

Table 2. Mean air temperature and rainfall during the growing period of carrot grown on mineral soil near Muck Crops Research Station, Holland Marsh, in 2006, 2007, and 2008. ${ }^{2}$

\begin{tabular}{|c|c|c|c|c|c|c|c|c|c|c|c|c|}
\hline \multirow[b]{2}{*}{ Month } & \multicolumn{6}{|c|}{ Temperature $\left({ }^{\circ} \mathrm{C}\right)$} & \multicolumn{6}{|c|}{ Total rainfall $(\mathrm{mm})$} \\
\hline & 2006 & LTA & 2007 & LTA & 2008 & $\overline{\text { LTA }}$ & $\overline{2006}$ & LTA & 2007 & LTA & 2008 & $\overline{\text { LTA }}$ \\
\hline May & 13.7 & 12.4 & 12.6 & 12.5 & 10.7 & 12.6 & 65 & 74 & 43 & 80 & 48 & 80 \\
\hline June & 18.4 & 18.3 & 18.8 & 18.3 & 19.2 & 18.4 & 64 & 76 & 29 & 77 & 68 & 76 \\
\hline July & 21.9 & 20.3 & 19.2 & 20.2 & 20.4 & 20.3 & 72 & 82 & 27 & 61 & 137 & 69 \\
\hline August & 19.2 & 19.1 & 19.7 & 19.1 & 17.9 & 19.2 & 41 & 81 & 22 & 57 & 63 & 56 \\
\hline September & 14.3 & 15.6 & 16.2 & 15.7 & 14.7 & 15.7 & 174 & 85 & 40 & 74 & 82 & 80 \\
\hline October & 7.9 & 8.8 & 12.5 & 9.1 & 7.4 & 9.0 & 102 & 68 & 32 & 56 & 54 & 59 \\
\hline Total rainfall & & & & & & & 518 & 466 & 193 & 405 & 452 & 420 \\
\hline
\end{tabular}

${ }^{2}\left(1.8 \times{ }^{\circ} \mathrm{C}\right)+32={ }^{\circ} \mathrm{F} ; 1 \mathrm{~mm}=0.0394$ inch. Temperature and rainfall data collected at weather station located near the mineral soil research trials at the University of Guelph Muck Crops Research Station (McDonald et al., 2006, 2007, 2008).

LTA= Long term average: 10-year mean (McDonald et al., 2006, 2007, 2008). rating at the $j$ th observation, and $n=$ total number of observations.

To assess the effect of fungal leaf blights on canopy health at harvest, the foliage of 10 carrots selected at random from each experimental unit was removed by hand on 26 or Oct. (2006) and 26 Oct. (2007 and 2008) ity. Leaf blight symptoms at harvest were not separated based on causal organism. Leaves and petioles were assessed for the amount of dead leaves and petioles and for disease disease $1=$ less than $10 \%$ leaf area $2=10 \%$ to $25 \%$ leaf area diseased; $3=26 \%$ leaf area diseased; $5=$ greater than $75 \%$ leaf and number of dead assessed at this time. Fungal leaf blight severity ratings were used to calculate a disease severity index (DSI) to transform the ratings to a 0 to 100 scale using the following equation (Kobriger and Hagedorn, 1983):

$$
\begin{aligned}
& \text { DSI } \\
& =\frac{\sum\left[\begin{array}{l}
(\text { class no. }) \times \\
(\text { no. of leaves in each class })
\end{array}\right]}{\left(\begin{array}{c}
\text { total no. leaves per sample }) \\
(\text { no. classes }-1)
\end{array}\right.} \times 100
\end{aligned}
$$

Carrot foliage with $10 \%$ or more of diseased leaf area is prone to break off the root when carrots are harvested mechanically (Langenberg, 1975).

Carrot yield assessment. Carrot plants in the center $4.6 \mathrm{~m}$ of the middle rows of each cent were hand-harvested on 30 Oct. in in 2008 . Carrots were weighed for total yield and separated into three size/quality grades (roots greater than $4.4 \mathrm{~cm}$ diameter, roots 2.0 to $4.4 \mathrm{~cm}$ diameter, and culls, including roots less than $2.2 \mathrm{~cm}$ in diameter) according to the Canadian Food Inspection Agency for vegetable inspections (Canadian Food Inspection Agency, 2011)

Relative cost of ammonium nitrate and the three fungicides applied was calculated based on the product's application rates and the retail prices as of July 2013 at a local farm supply store (Scotland Agromart, Scotland, Ontario, Canada). to $50 \%$ leaf area diseased; $4=51 \%$ to $75 \%$ 
Statistical analysis. Data were analyzed by analysis of variance (ANOVA) and regression analysis using the GLM procedures of SAS software (Version 9.2; SAS Institute, Cary, NC). The Shapiro-Wilk statistic was calculated and residuals were plotted using PROC PLOT and PROC UNIVARIATE. Studentized residuals were determined for all data, and individual measurements were rejected if the critical value was higher than the respective calculated Lund's value (Lund, 1975). Each year's data were analyzed individually because the number of fungicides applied combined with $\mathrm{N}$ rates differed slightly over the 3 years. However, data from treatments that were common over the 3 years - $0 \%$, $100 \%$, and $200 \% \mathrm{~N}$ rates and zero, three, and five/six fungicide applications-were used for the response surface analysis using PROC GLM. A type I error rate of 0.10 was used to determine which terms to include in the response surface regression models. When ANOVA was carried out, Tukey's Studentized range, honestly significant difference test at $P=0.05$ was used for mean separations, unless otherwise indicated.

\section{Results}

Soil tests before seeding indicated that the amount of nitrate- $\mathrm{N}\left(\mathrm{NO}_{3}-\mathrm{N}\right)$ in the soil was 0 ppm in 2006 and 2007 and 14 ppm in 2008; therefore, there was minimal available $\mathrm{N}$ present in the soil at trial initiation.
Fungal leaf blight symptoms were first recorded on 2 Aug., $65 \mathrm{~d}$ after seeding (DAS) in 2006, on 31 July, 70 DAS in 2007 and on 29 July, 70 DAS in 2008. Fungal leaf blight development in 2006 was moderate and the weather conditions were less favorable for disease development early in the season. In 2007 the disease development was slow as a result of dry and hot weather conditions in early summer, but disease severity increased by harvest. In 2008 the weather conditions in early summer were favorable for fungal leaf blight development, and disease pressure was high throughout the growing season (Table 2). Disease incidence was $100 \%$ across all treatments in all years. As a result, disease severity provides a better comparison among
2007

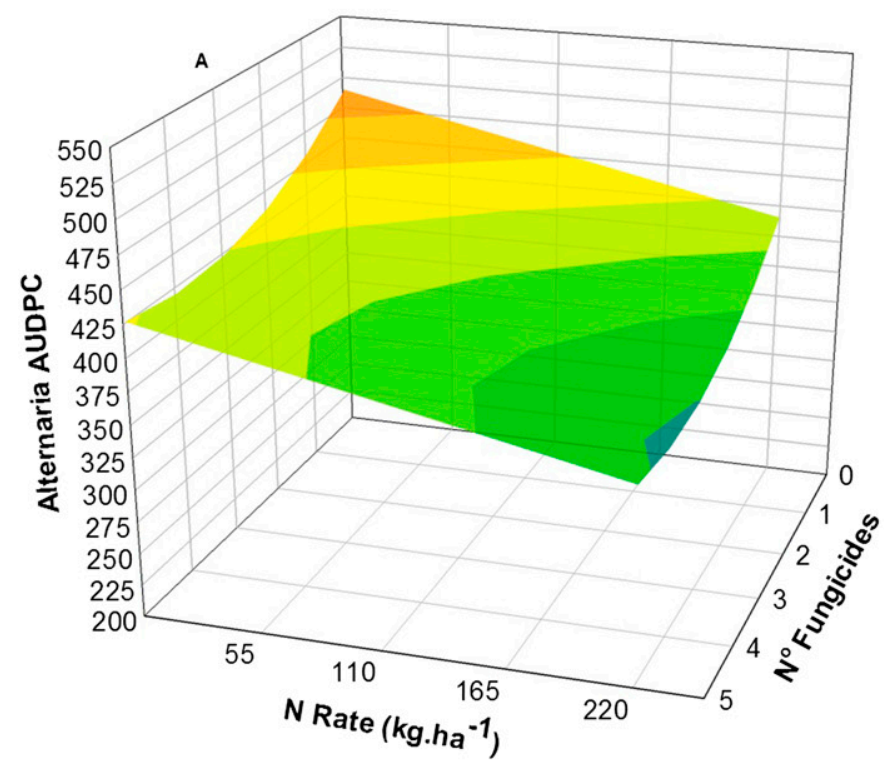

2007

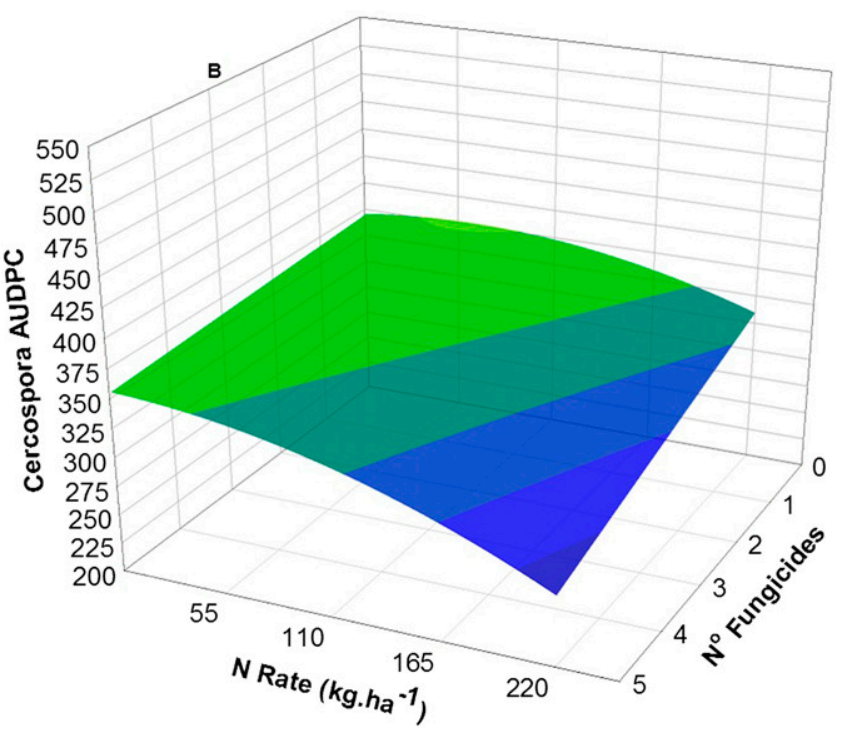

2008

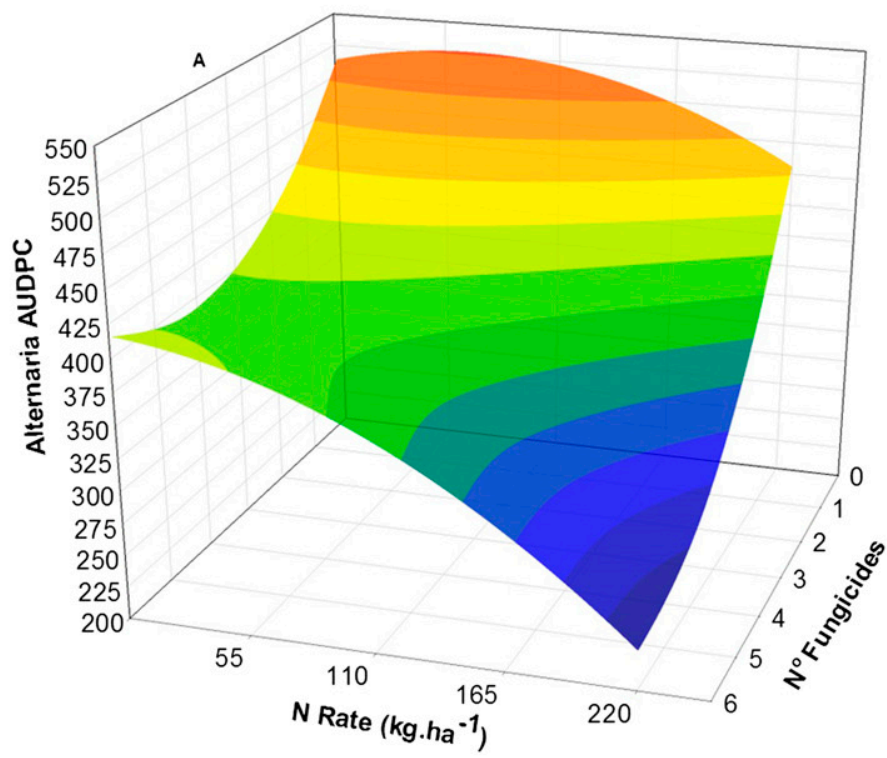

2008

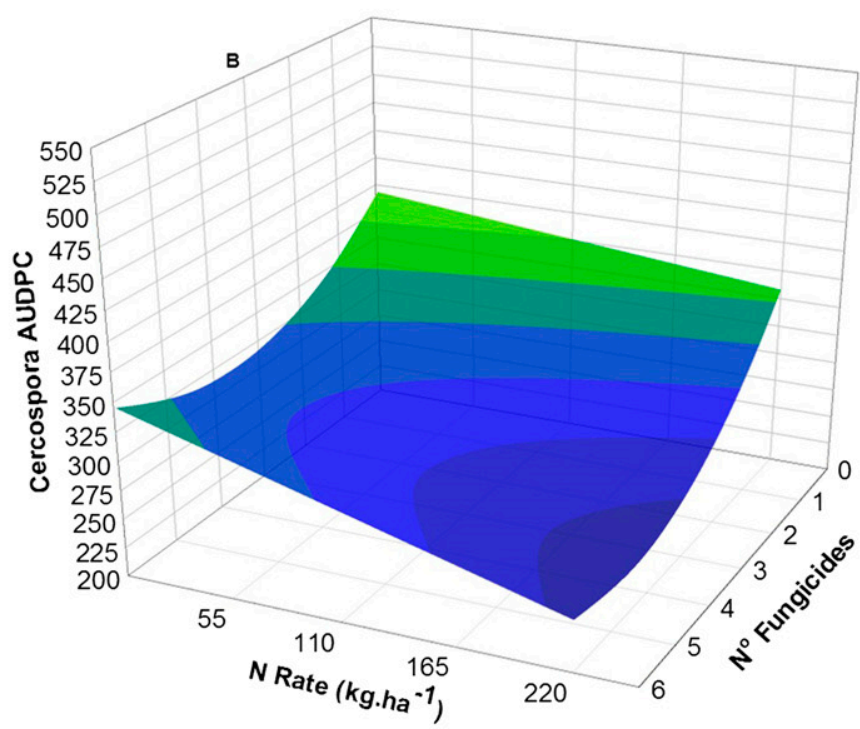

Fig. 1. Effect of nitrogen $(\mathrm{N})$ rate and number of fungicide applications on area under the disease progress curve (AUDPC) of Alternaria leaf blight $($ Alt $):($ A $)$ Alt $=$ $490.31-0.340 \times \mathrm{Nit}-35.93 \times$ Fung $+4.68 \times \mathrm{Fung}^{2}, R^{2}=0.74(2007) ;$ Alt $=512.99+0.423 \times \mathrm{Nit}-0.0031 \times \mathrm{Nit}^{2}-57.58 \times \mathrm{Fung}^{2}+6.92 \mathrm{Fung}^{2}-0.0975 \times \mathrm{Nit}^{2}$ Fung, $R^{2}=0.85(2008)$, and Cercospora leaf spot $(\mathrm{Cer})(\mathbf{B}) \mathrm{Cer}=370.76+0.209 \times \mathrm{Nit}-0.001 \times \mathrm{Nit}^{2}-2.631 \times$ Fung $-0.053 \times \mathrm{Nit} \times \mathrm{Fung}, R^{2}=0.59(2007), \mathrm{Cer}=$ $393.71-0.162 \times \mathrm{Nit}-42.18 \times$ Fung $+5.71 \times$ Fung $^{2}-0.05 \times \mathrm{Nit} \times \mathrm{Fung}, R^{2}=0.71$ (2008) of carrots grown on a mineral soil. 
treatments and is presented in this study. There were year-by-treatment interactions; therefore, data could not be combined among years and are reported separately.

In 2006, $\mathrm{N}$ alone did not have any effect on ALB or CLS AUDPC throughout the growing season, but disease severity during the season decreased with increasing fungicide application (data not shown: Cercospora AUDPC $=366.3-18.08 \times$ number
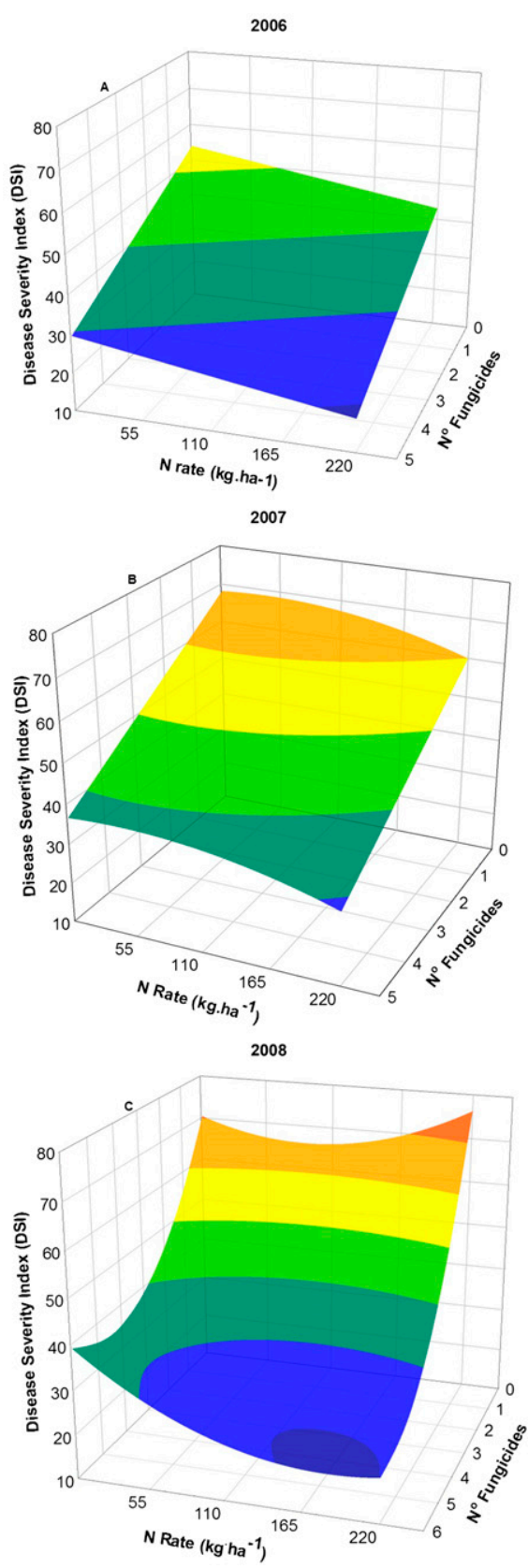

Fig. 2. Effect of nitrogen $(\mathrm{N})$ rate and number of fungicide applications on disease severity index (DSI) of fungal blight (Alternaria leaf blight and Cercospora leaf spot) of carrots grown on a mineral soil: $(\mathbf{A})$ DSI $=54.062-$ $0.05 \times$ Nit $-4.88 \times$ Fung, $R^{2}=0.68(2006)$; (B) $\mathrm{DSI}=68.19+0.022 \times \mathrm{Nit}-0.00027 \times \mathrm{Nit}^{2}-$ $6.30 \times$ Fung, $R^{2}=0.85$ (2007); and (C) DSI = $70.57-0.106 \times \mathrm{Nit}+0.0006 \times \mathrm{Nit}^{2}-15.70 \times$ Fung $+1.753 \times$ Fung $^{2}-0.019 \times$ Nit $\times$ Fung $R^{2}=0.90$ (2008). of fungicides, $R^{2}=0.38$; Alternaria $\mathrm{AUDPC}=$ $354.6-16.26 \times$ number of fungicides, $R^{2}=$ 0.48). In 2007, the severity of both ALB and CLS during the growing season, based on AUDPC, was lower with high $\mathrm{N}$ and five fungicide applications and highest with no $\mathrm{N}$ or fungicide (Fig. 1). For ALB, the effect of $\mathrm{N}$ application was greater than the effect of fungicide application as shown in Figure 1. The AUDPC for CLS was similar between the no fungicides and high $\mathrm{N}$ treatment and the no $\mathrm{N}$ and five fungicide application treatment, and the effect of $\mathrm{N}$ was similar to the effect of fungicides in reducing disease severity.

In 2008, ALB and CLS AUDPC during the growing season was lowest with high $\mathrm{N}$ and fungicide application (Fig. 1). However, the effect of fungicide application was greater than that of $\mathrm{N}$ application for both diseases. The AUDPC of both diseases was similar between no $\mathrm{N}$ and six fungicides and high $\mathrm{N}$ and two fungicides. The effect of $\mathrm{N}$ in reducing both ALB and CLS was low when no fungicides were applied.

At the harvest assessment, combined ALB and CLS severity decreased with increasing $\mathrm{N}$ and fungicide application as shown by regression analysis (Fig. 2). Disease severity was lowest with high $\mathrm{N}$ and fungicide applications and highest with both no $\mathrm{N}$ and no fungicides. The decrease in disease severity as a result of the application of fungicides was greater than the decrease from increasing $\mathrm{N}$ application. Disease severity was similar between the treatment receiving five fungicide applications and no $\mathrm{N}$ and the treatment receiving the high rate of $\mathrm{N}$ and two fungicide applications (Fig. 2). A similar trend was found for combined DSI at harvest in both 2007 and 2008, but the effect of fungicides was much greater than the effect of $\mathrm{N}$ in both years (Fig. 2).

The efficacy of half rates of the fungicides differed between 2007 and 2008. In 2007 the half rate of fungicide applied five times, in combination with $220 \mathrm{~kg} \mathrm{~N}$, resulted in DSI (38) that was higher than the full rate of fungicide with high $\mathrm{N}(26)$ and similar to the full rate of fungicide in five sprays in combination with $110 \mathrm{~kg} \mathrm{~N} \mathrm{(40).} \mathrm{In} 2008$ there were no differences in DSI between full and half rates of fungicide at any of the $\mathrm{N}$ rates (data not shown).

Regression analysis showed that marketable yield was unaffected by $\mathrm{N}$ application in 2006 or 2007. Marketable yield increased $(15 \%, 2006 ; 10 \%, 2007)$ with increasing number of fungicide applications [marketable yield $=34.71+2.089 \times$ number of fungicide applications, $R^{2}=0.21$ (2006); marketable yield $=40.42+1.82 \times$ number of fungicide applications (2007), $\left.R^{2}=0.21\right]$. In 2008, marketable yield decreased with increasing $\mathrm{N}$ application and increased $(18 \%)$ with increasing fungicide application (Fig. 3). Some of the highest yields occurred in the no $\mathrm{N}$ treatments. The percentage of roots larger than marketable size was highest in high $\mathrm{N}$ and fungicide treatments (Table 3 ). The percentage of culls was unaffected by either $\mathrm{N}$ or fungicide application. The application of the half rate of fungicides in 2007 and 2008 did not affect ALB or CLS severity and yield compared with the full rate of fungicides at the same $\mathrm{N}$ rate (Table 3 ). The number of dead leaves per plant at harvest was decreased by fungicide application but was unaffected by $\mathrm{N}$ application (Table 2).

There was no significant correlation between $\mathrm{N}$ rate and yield in any of the 3 years, but there was a positive correlation between number of fungicide applications and both total and marketable yield (Table 4). In general, both ALB and CLS severity and DSI of combined disease at harvest were negatively correlated with total yield, but there were fewer significant correlations between DSI and marketable yield (Table 4).

At current prices, the cost per hectare of the high $\mathrm{N}$ treatment is half to one-third the cost of the high fungicide treatment, depending on the fungicides used in each year (Table 5).

\section{Discussion}

The severity of both ALB and CLS of carrot was affected by both $\mathrm{N}$ and fungicide application. This is the first study to show that a combination of $\mathrm{N}$ and fungicides is necessary to provide optimal control of both diseases. Fungicide application increased marketable yield of carrots, but $\mathrm{N}$ application either did not affect, or decreased, carrot yield. These results are similar to previous studies (Westerveld et al., 2002, 2008). The lack of a yield response to $\mathrm{N}$ application occurred despite the removal of residual $\mathrm{N}$ by a previous carrot crop. There was a significant negative correlation between fungicide application and disease severity in most cases. As disease severity increased, total yield decreased, but the relationship between disease severity and marketable yield was not as strong. This was likely the result of the reduction in stand and the increase in oversized roots as a result of high $\mathrm{N}$ application,

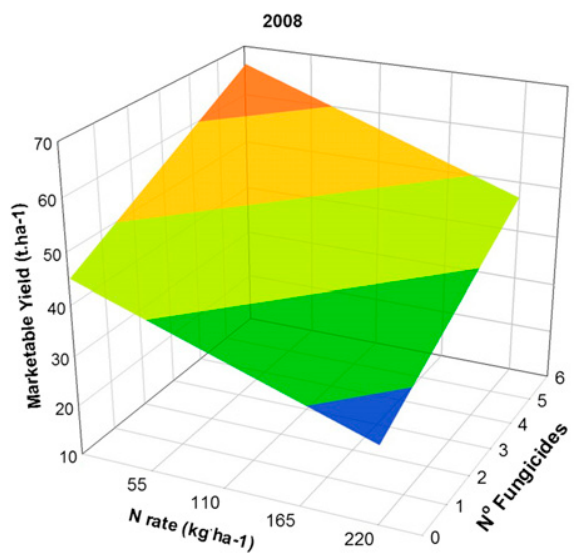

Fig. 3. Effect of nitrogen $(\mathrm{N})$ rate and number of fungicide applications on marketable yield (Mkt) of carrots grown on a mineral soil and infected with Alternaria leaf blight and Cercospora leaf spot: $\mathrm{Mkt}=45.17-0.039 \times \mathrm{Nit}+$ $3.55 \times$ Fung, $R^{2}=0.33$ in 2008 . 


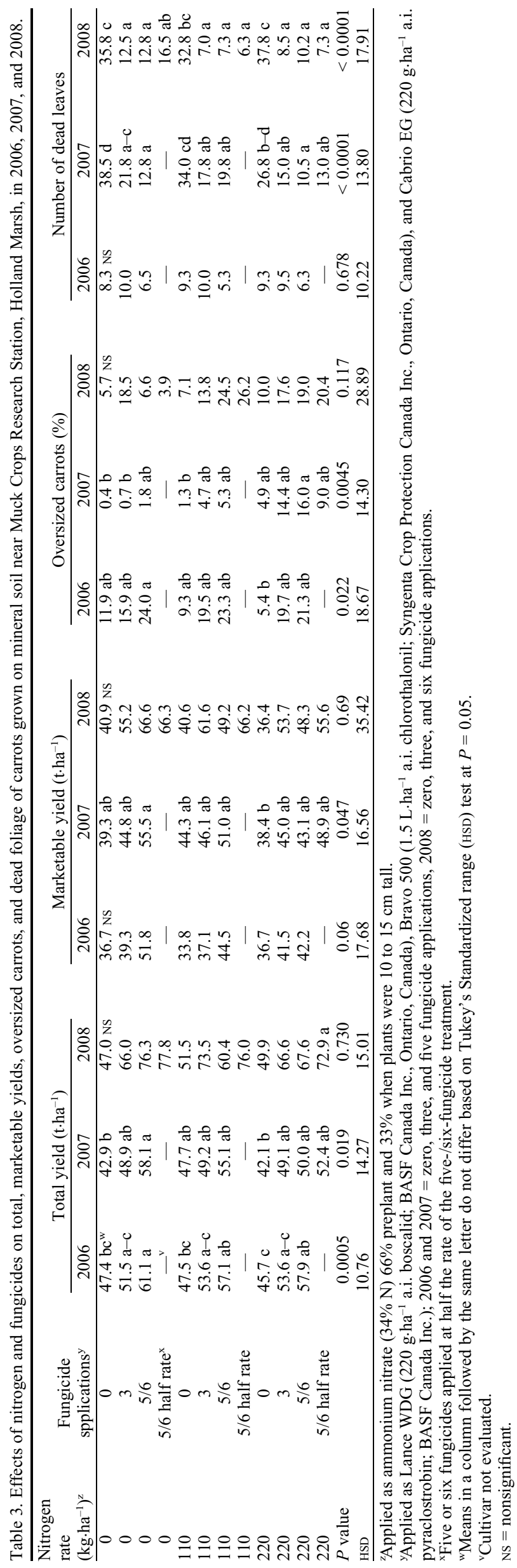

which would not have been influenced by disease severity. The effect of both fungicides and $\mathrm{N}$ application on the strength of the tops and the ability to withstand mechanical harvest was not examined directly. Therefore, low $\mathrm{N}$ and fungicide application may have more effect on harvestable yield than this study identified because canopy health at harvest was lower in these treatments.

The effects of $\mathrm{N}$ in reducing the severity of ALB and CLS in this study confirm previous reports in the literature (Vintal et al., 1999; Warncke, 1996; Westerveld et al., 2002, 2008). The efficacy of fungicides to reduce the severity of these diseases is expected, because efficacy data are required in the registration process for fungicides in Canada.

Optimal disease control in this study was achieved by combining frequent fungicide applications with $220 \mathrm{~kg} \cdot \mathrm{ha}^{-1} \mathrm{~N}$, the highest rate tested. Previous studies have compared N and fungicide application for control of diseases caused by Alternaria species (Blachinski et al., 1996; Vintal et al., 1999), but their conclusions differed from the current study. In a study on early blight of tomato caused by Alternaria solani, Blachinski et al. (1996) examined the effect of foliar applied $\mathrm{N}$ on disease severity but concluded that the effect was minimal, occurring only in vitro, and fungicides were required to control disease. The effect of $\mathrm{N}$ on disease severity in the current study was much greater. Vintal et al. (1999) studied the effect of increasing $\mathrm{N}$ fertilization from a recommended rate of $10 \mathrm{~kg} \cdot \mathrm{ha}^{-1}$ each week (equivalent to $\approx 130 \mathrm{~kg} \cdot \mathrm{ha}^{-1}$ during the season) to a high rate of $30 \mathrm{~kg} \cdot \mathrm{ha}^{-1}$ each week on ALB severity on carrots. They concluded that the additional cost of $\mathrm{N}$ to control disease was higher than the cost of fungicides, and ALB should be maintained by properly timed fungicide applications. The current study showed minimal effect of $\mathrm{N}$ application on yield of carrots, which makes adjustment of $\mathrm{N}$ application rates to control disease a more viable option for carrot growers.

In this study, the average interval between fungicide applications in the five- or sixfungicide regime was $10 \mathrm{~d}$ except for a $25-\mathrm{d}$ interval between the fourth and fifth fungicide applications in 2006, which was the result of inappropriate weather conditions for fungicide application. This is within the recommended interval of 7 to $14 \mathrm{~d}$ for boscalid and pyraclostrobin and 7 to $10 \mathrm{~d}$ for chlorothalonil. It is possible that improved disease control could have been achieved with a 7-d spray interval, and if this was the case, the effect of $\mathrm{N}$ would likely have been reduced.

The efficacy of half rates of fungicide was evaluated. There were few differences in disease severity and no differences in total or marketable yield when half rates of the full number of fungicides (five or six) were applied. The use of lower than label rates of fungicide is not recommended because this can contribute to the development of fungicide resistance. The effect of $\mathrm{N}$ and fungicides on ALB and CLS AUDPC and combined DSI at harvest was lower in 2006 than in the other 
Table 4. Correlations between the severity of Alternaria leaf blight and Cercospora leaf spot during the growing season and at harvest (DSI), nitrogen rate, fungicide applications, and total and marketable yields from 2006 to 2008.

\begin{tabular}{|c|c|c|c|c|c|c|c|c|c|c|c|c|}
\hline \multirow[b]{3}{*}{ Parameters evaluated } & \multicolumn{4}{|c|}{2006} & \multicolumn{4}{|c|}{2007} & \multicolumn{4}{|c|}{2008} \\
\hline & \multicolumn{2}{|c|}{$\begin{array}{c}\text { Total } \\
\text { yield }\left(\mathrm{t} \cdot \mathrm{ha}^{-1}\right)\end{array}$} & \multicolumn{2}{|c|}{$\begin{array}{c}\text { Marketable } \\
\text { yield }\left(\mathrm{t} \cdot \mathrm{ha}^{-1}\right)\end{array}$} & \multicolumn{2}{|c|}{$\begin{array}{c}\text { Total } \\
\text { yield }\left(\mathrm{t} \cdot \mathrm{ha}^{-1}\right)\end{array}$} & \multicolumn{2}{|c|}{$\begin{array}{c}\text { Marketable } \\
\text { yield }\left(\mathrm{t} \cdot \mathrm{ha}^{-1}\right)\end{array}$} & \multicolumn{2}{|c|}{$\begin{array}{c}\text { Total } \\
\text { yield }\left(\mathrm{t} \cdot \mathrm{ha}^{-1}\right)\end{array}$} & \multicolumn{2}{|c|}{$\begin{array}{l}\text { Marketable } \\
\text { yield }\left(\mathrm{t} \cdot \mathrm{ha}^{-1}\right)\end{array}$} \\
\hline & $r^{2}$ & $P$ value & $r^{2}$ & $P$ value & $r^{2}$ & $P$ value & $r^{2}$ & $P$ value & $r^{2}$ & $P$ value & $r^{2}$ & $P$ value \\
\hline Nitrogen rate ${ }^{z}$ & -0.06 & $0.721^{\mathrm{v}}$ & -0.09 & 0.580 & -0.09 & 0.541 & -0.15 & 0.352 & -0.06 & 0.700 & -0.22 & 0.142 \\
\hline Fungicide applications ${ }^{\mathrm{y}}$ & 0.76 & 0.000 & 0.46 & 0.004 & 0.42 & 0.006 & 0.37 & 0.018 & 0.57 & 0.000 & 0.53 & 0.000 \\
\hline Alternaria AUDPC ${ }^{\mathrm{x}}$ & -0.55 & 0.000 & -0.24 & 0.166 & -0.20 & 0.201 & -0.09 & 0.567 & -0.35 & 0.016 & -0.22 & 0.138 \\
\hline Cercospora AUDPC ${ }^{\mathrm{x}}$ & -0.47 & 0.003 & -0.17 & 0.314 & -0.02 & 0.896 & 0.12 & 0.433 & -0.26 & 0.078 & -0.13 & 0.377 \\
\hline $\begin{array}{l}\text { Disease severity index } \\
\text { at harvest }\end{array}$ & -0.49 & 0.002 & -0.23 & 0.173 & -0.41 & 0.007 & -0.29 & 0.068 & -0.52 & 0.000 & -0.46 & 0.001 \\
\hline
\end{tabular}

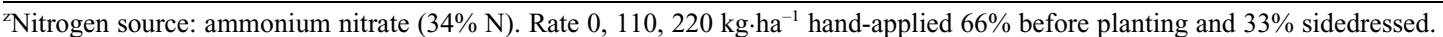

${ }^{y}$ Fungicides were: Lance WDG (220 g.ha ${ }^{-1}$ a.i. boscalid), Bravo 500 (1.5 L.ha ${ }^{-1}$ a.i. chlorothalonil), and Cabrio EG (220 g.ha ${ }^{-1}$ a.i. pyraclostrobin). Fungicide applications regime: no fungicide, three, five applications (2006 and 2007), and six (2008).

${ }^{\times}$Alternaria and Cercospora area under the disease progress curve (AUDPC) rating scale of 0 to $10(0=$ no lesions, $1=1$ to 10 lesions on leaves, $2=11$ to 20 lesions on leaves, $3=21$ to 30 lesions on leaves, 1 to 10 lesions on petioles, $4=31$ to 40 lesions on leaves, 11 to 20 lesions on petioles, $5=41$ to 60 lesions on leaves, 21 to 40 lesions on petioles, $6=>60$ lesions on leaves, $>40$ lesions on petioles, $7=1 \%$ to $25 \%$ of leaves destroyed, $8=26 \%$ to $50 \%$ leaves destroyed, $9=51 \%$ to $75 \%$ of leaves destroyed, and $10=75 \%$ to $100 \%$ leaves destroyed) was used. Biweekly disease ratings were used to calculate area under the disease progress curve (AUDPC). "Disease severity index (DSI): assessed on leaves and petioles at harvest using the equation DSI $=\left[\sum\right.$ (class no.) $\times($ no. of leaves in each class) $] /($ total no. of leaves $\times$ no. classes -1$) \times 100$, equation adapted from Kobriger and Hagedorn (1983). Severity classes were: $0=$ no disease; $1=1$ less than $10 \%$ leaf area diseased; $2=10 \%$ to $25 \%$ leaf area diseased; $3=26 \%$ to $50 \%$ leaf area diseased; $4=51 \%$ to $75 \%$ leaf area diseased; $5=$ greater than $75 \%$ leaf area diseased $/$ dead.

vearson correlation analyses, $P<0.05$.

Table 5. Comparison of relative costs of nitrogen and fungicides in controlling Alternaria leaf blight and Cercospora leaf spot of carrots grown on mineral soil near Muck Crops Research Station, Holland Marsh, in 2006, 2007 , and 2008 .

\begin{tabular}{lc}
\hline Treatment & Costs $(\$ / \mathrm{ha})^{\mathrm{z}}$ \\
\hline $110 \mathrm{~kg} \cdot \mathrm{ha}^{-1}$ nitrogen $^{y}$ & 75 \\
$220 \mathrm{~kg} \cdot \mathrm{ha}^{-1}$ nitrogen $^{\mathrm{T}}$ & 151 \\
Three fungicides & $210-288$ \\
Five or six fungicides & $270-420$ \\
\hline
\end{tabular}

${ }^{2}$ Prices in 2013.

${ }^{\mathrm{y}}$ Nitrogen source: ammonium nitrate $34 \%$, $\$ 0.685 / \mathrm{kg}$.

${ }^{\mathrm{x}}$ Fungicides: Lance (boscalid 70\%), \$51/ha; Bravo (chlorothalonil 50\%), \$30/ha Cabrio (pyraclostrobin $20 \%)$, \$129/ha.

2 years. Disease pressure throughout the season and at harvest was lower in 2006 as a result of less favorable weather conditions and a slightly delayed appearance of symptoms in the field compared with the other 2 years. This lower disease pressure may have resulted in smaller differences among treatments and reduced the ability to identify statistically significant differences among treatments. Although it is typical for carrot growers to initiate fungicide sprays once disease severity increases to a level that may cause economic damage, adjusting $\mathrm{N}$ applications is not practical at the time of year ALB and CLS usually develop. Consequently, decisions on $\mathrm{N}$ application rates would have to be made at the beginning of the growing season, and effects of $\mathrm{N}$ on disease severity later in the season may be reduced in years with lower disease pressure.

The mode of action of $\mathrm{N}$ in reducing disease pressure is not fully understood. ALB is known to be more severe on weakened and senescing tissues. Nitrogen can affect ALB severity by delaying leaf senescence and improving plant defenses (Vintal et al., 1999). On the other hand, CLS is not influenced by leaf senescence and often infects younger tissues. It is possible that additional $\mathrm{N}$ application promotes new leaf growth, which would temporarily reduce both fungal leaf blight severity ratings. Because CLS would quickly develop on the new leaves, the net effect of new leaf production on yield may be minimal. Any yield effect of the new leaf production would also be counteracted by a reduction in stand earlier in the season.

The disease reduction caused by the combination of high $\mathrm{N}$ and fungicide applications does not necessarily warrant the additional costs. In 2 of the 3 years of the study, the application of a high rate of $\mathrm{N}$ with no fungicides provided equivalent or similar disease control to five or six fungicide applications and no N. Deciding which input to focus on for minimizing disease will depend on the costs of each input. At 2013 prices, the cost of the fungicides alone in the fiveor six-fungicide application treatment was two to three times the cost of the high rate of $\mathrm{N}$. This does not include labor costs for application of the products, which would be higher for the fungicides because of the multiple applications required. At current prices, $\mathrm{N}$ application would be recommended to reduce fungicide requirements, but this may change if $\mathrm{N}$ prices increase relative to fungicide prices. However, the method of $\mathrm{N}$ delivery may have to be adjusted for mineral soils to avoid effects on plant stand.

Plant stand decreases with increasing $\mathrm{N}$ application on mineral soils (Westerveld et al., 2006). As a result, roots can be larger and yields reduced when excessive $\mathrm{N}$ is applied. In this study, the highest yields were achieved in plots with no applied N. A slight reduction in stand occurred at the high $\mathrm{N}$ rate and there was a significant increase in the number of oversized carrots. Thus, although high rates of $\mathrm{N}$ contribute to disease control, the yield results suggest they should be avoided on mineral soils. However, there were fewer live leaves at harvest as $\mathrm{N}$ application decreased, potentially reducing harvestable yield when low $\mathrm{N}$ is applied. The reduction in yield at high $\mathrm{N}$ application rates in the current study did not occur in a previous study on carrot despite higher $\mathrm{N}$ rates in that study (Vintal et al., 1999). In the previous study, $\mathrm{N}$ was applied weekly after seeding in the irrigation system. It is possible that application of $\mathrm{N}$ after seeding would eliminate the impact of $\mathrm{N}$ application on carrot stand and increase the benefits of high $\mathrm{N}$ application. However, drip irrigation is not currently economical for Ontario carrot growers. There are several other methods of $\mathrm{N}$ application that could be investigated to avoid the impact of $\mathrm{N}$ on seedling death and marketable yield on mineral soils. These options include banding $\mathrm{N}$ below and to the side of the seed at seeding, sidedress application a few weeks after seeding, and the use of controlled-release $\mathrm{N}$ fertilizers. This could make $\mathrm{N}$ application a method to reduce fungal leaf blight severity a more feasible option for growers on mineral soils, but the effects of $\mathrm{N}$ application on fungal leaf blight severity using these methods would have to be confirmed.

The current study was conducted on a soil with low residual N. This provided conditions typical of coarse sandy soils with low residual $\mathrm{N}$ and allowed for determination of the $\mathrm{N}$ levels required to get a yield response. However, the results suggest that there was residual $\mathrm{N}$ deeper in the soil profile that was not detected by a regular soil test. High yields were found in treatments that received no $\mathrm{N}$ application, although there was low residual N. Carrots certainly require $\mathrm{N}$ for growth. Previous work has shown that carrots can access $\mathrm{N}$ from deep in the soil profile (Westerveld et al., 2006).

The response of carrots and fungal blights to $\mathrm{N}$ application may have been greater in this trial than in other soils with high residual $\mathrm{N}$. However, a response of ALB and CLS to N application has also been found on organic soils with high organic matter content $(60 \%$ to $80 \%$ ) and high residual $\mathrm{N}$ (Westerveld et al., 2008), which suggests that the fungal leaf blight response to $\mathrm{N}$ application may be unaffected by the amount of residual $\mathrm{N}$ in the soil at the beginning of the growing season. There is no effect of $\mathrm{N}$ application on yield of carrots on organic soils with high organic 
matter content (Westerveld et al., 2006). Although the current study did not examine the response in organic soils, results may be similar on organic soils based on the results of previous studies. Even with very low concentrations of available $\mathrm{N}$ at the beginning of the growing season, the application of $\mathrm{N}$ did not increase carrot yield in any of the 3 years of the study.

The application of $\mathrm{N}$ has minimal impact on yield of carrots on both organic and mineral soils, especially at or below current recommendations. However, management of fungal leaf blights of carrot is improved if at least $110 \mathrm{~kg} \cdot \mathrm{ha}^{-1}$ of $\mathrm{N}$ is applied on a mineral soil. Both fungicides and $\mathrm{N}$ are expensive to apply and can potentially have environmental consequences if overused. As a result, following current recommendations for both fungicide and $\mathrm{N}$ application would provide adequate disease control without reducing root quality or adding to grower costs. The potential to avoid the effects of high $\mathrm{N}$ on seedling death through other methods of $\mathrm{N}$ application should also be investigated. If the incidence and severity of fungal leaf blights can be reduced through other means such as the use of resistant cultivars and improved disease forecasting, growers may be able to reduce both $\mathrm{N}$ rates and the number of fungicide applications without affecting yield.

\section{Literature Cited}

Ben-Noon, E., D. Shtienberg, E. Shlevin, and H. Vintal. 2001. Optimization of chemical suppression of Alternaria dauci, the causal agent of Alternaria leaf blight in carrots. Plant Dis. 85:1149-1156.

Blachinski, D., D. Shtienberg, A. Dinoor, U. Kafkafi, L.S. Sujkowski, T.A. Zitter, and W.E. Fry. 1996. Influence of foliar application of nitrogen and potassium on Alternaria diseases in potato, tomato and cotton. Phytoparasitica 24:281292.

Canadian Food Inspection Agency. 2011. Vegetable inspection manuals. Carrots - Grades and sizes. 8 Oct. 2013. <http://www.inspection. gc.ca/food/fresh-fruits-and-vegetables/quality- inspection/vegetable-inspection-manuals/carrots/ eng/1303762739912/1303762802189>.

Carisse, O. and A.C. Kushalappa. 1992. Influence of interrupted wet periods, relative humidity, and temperature on infection of carrots by Cercospora carotae. Phytopathology 82:602606.

Gugino, B.K., J.E. Carroll, P. Chen, J.W. Ludwig, and G.S. Abawi. 2004. Carrot leaf blight diseases and their management in New York. Vegetables IPM Fact Sheet. NYS IPM Program, Cornell Univ., Geneva, NY.

Hooker, J.W. 1944. Comparative studies of two carrot leaf diseases. Phytopathology 34:606612.

Huber, D.M. and R.D. Watson. 1974. Nitrogen form and plant disease. Annu. Rev. Plant Pathol. 12:139-165.

Jones, J.B.J. 1999. Soil analysis handbook of reference methods. Soil and Plant Analysis Council.

Kobriger, K.M. and D.J. Hagedorn. 1983. Determination of bean root rot potential in vegetable production fields of Wisconsin's Central Sands. Plant Dis. 67:177-178.

Langenberg, W.J. 1975. Carrot leaf blight (Alternaria dauci) development in relation to environmental factors and fungicide applications. PhD thesis, University of Guelph, Guelph, Ontario, Canada.

Lund, R.E. 1975. Tables for an approximate test for outliers in linear models. Techometrics 17:473-476.

MacKenzie, D.R. 1981. Association of potato early blight, nitrogen fertilizer rate and Potato yield. Plant Dis. 65:575-577.

Marschner, H. 1995. Relationship between mineral nutrition and plant diseases and pests, p. 436460. In: Marschner, H. (ed.). Mineral nutrition of higher plants. 2nd Ed. Academic Press, London, UK.

McDonald, M.R., S. Janse, and K. Vander Kooi. 2006. Muck vegetable cultivar and research reports_-Weather data. 56:9-16. 8 Oct. 2013. $<$ http://www.uoguelph.ca/muckcrop $>$.

McDonald, M.R., S. Janse, and K. Vander Kooi. 2007. Muck vegetable cultivar and research reports-Weather data. 57:9-16. 8 Oct. 2013. $<$ http://www.uoguelph.ca/muckcrop $>$.

McDonald, M.R., S. Janse, and K. Vander Kooi. 2008. Muck vegetable cultivar and research reports - Weather data. 58:9-16. 8 Oct. 2013. $<$ http://www.uoguelph.ca/muckcrop $>$.
OMAFRA. 2012. Vegetable production recommendations 2012-2013. Publication 363. Queen's Printer for Ontario, Toronto, Ontario, Canada.

OMAF. 2013. Horticultural crops. Vegetables: Area, production, value, price and yield by crop-Carrots. 8 Oct. 2013. <http://www. omafra.gov.on.ca/english/stats/hort/carrots.htm>.

Pryor, B.M. and J.O. Strandberg. 2002. Alternaria leaf blight of carrot, p. 15-16. In: Davis, R.M., and R.N. Raid (eds.). Compendium of umbelliferous crop diseases. American Phytopathological Society, St. Paul, MN.

Soltanpour, E.N. and M.D. Harrison. 1974. Interrelations between nitrogen and phosphorus fertilization and early blight control of potatoes. Amer. Potato J. 51:1-7.

Thomas, H.R. 1943. Cercospora blight of carrot. Phytopathology 33:114-125.

Tremblay, M.H.M. and F. Charbonneau. 1993. Plant nutrient composition as a component of crop protection. Acta Hort. 339:85-97.

Vintal, H., E. B.-N, E. Shlevin, U. Yermiyahu, D. Shtienberg, and A. Dinoor. 1999. Influence of rate of soil fertilization on alternaria leaf blight (Alternaria dauci) in carrots. Phytoparasitica 27:193-200.

Warncke, D.D. 1996. Soil and plant tissue testing for nitrogen management in carrots. Commun. Soil Sci. Plant Anal. 27:597-605.

Westerveld, S.M. 2002. Nitrogen management of cabbage, onions, and carrots as part of an integrated crop management program in Ontario. Master's thesis, University of Guelph, Guelph, Ontario, Canada.

Westerveld, S.M., M.R. McDonald, and A.W. McKeown. 2006. Carrot yield, quality, and storability in relation to preplant and residual nitrogen on mineral and organic soils. HortTechnology 16:286-293.

Westerveld, S.M., M.R. McDonald, C.D. ScottDupree, and A.W. McKeown. 2002. The effect of nitrogen on insect and disease pests of onions, carrots, and cabbage. J. Veg. Crop Prod. 8:87-99.

Westerveld, S.M., A.W. McKeown, and M.R. McDonald. 2008. Relationship between nitrogen fertilization and Cercospora leaf spot and Alternaria leaf blight of carrot. HortScience 43:1522-1527.

White, J.M., J.O. Strandberg, and R.L. Brown. 1983. Influence of fertilizer on Alternaria leaf blight and yield of carrots grown in muck. Proc. Soil Crop Sci. Soc. Fla. 42:153-157. 